\title{
Hubungan Kecemasan dengan Performa Atlet Bola Voli pada Event Kejuaraan Antar Desa Di Desa Orimalang Kec. Jamblang Kab. Cirebon
}

\author{
Yucky Putri Erdiyanti ${ }^{1}$, Agus Maulana ${ }^{2}$ \\ ${ }^{1}$ Universitas Majalengka \\ Email Penulis ${ }^{1}$ : yuckyerdiyanti@gmail.com \\ ${ }^{2}$ Universitas Majalengka \\ Email Penulis ${ }^{2}$ : achilagus03@gmail.com
}

\begin{abstract}
Abstrak
Berdasarkan hasil observasi I, II, dan III terdapat adanya hubungan antara kecemasan dan performa. Secara statistika koefisen korelasi yang ditemukan pada pertandingan pertama sebesar 0,404 pada tingkat hubungan sedang. Hasil korelasi yang ditemukan pada pertandingan kedua sebesar 0,583 pada tingkat hubungan sedang. Hasil korelasi yang ditemukan pada pertandingan ketiga sebesar 0,567 pada tingkat hubungan sedang. Berdasarkan teori dan hasil perhitungan statistika menyatakan bahwa adanya hubungan antara kecemasan dan performapada atlet bola voli pada event kejuaraan antar Desa di Desa Orimalang Kecamatan Jamblang Kabupaten Cirebon.
\end{abstract}

Kata Kunci: Kecemasan; Performa Atlet; Bola Voli.

\section{PENDAHULUAN}

Pertandingan bola voli dimainkan pada atlet putra dan atlet putri. Namun untuk dapat memenangkan kejuaraan dalam pertandingan bola voli, seorang atlet pemain bola voli memiliki tingkat kecemasan dalam suatu pertandingan, disebabkan kepercayaaan diri seorang atlet pemain bola voli sangat dibutuhkan dalam suatu pertandinganuntuk dapat menekankan rasa kecemasan seorang atlet serta motivasi dan dukungan baik dari pelatih, supporter, orang tua dan rekan satu tim akan meningkatkan performa atlet pemain bola voli.

Menurut Setyobroto (2002) "tanpamemiliki penuh rasa percaya diri sendiri atlet tidak akan dapat mencapai prestasi tinggi, karenaada hubungan antara motif berprestasi dan percaya diri. Percaya diri adalah rasa percaya bahwa iasanggup dan mampu untuk mencapai prestasi tertentu; apabila prestasinya sudah tinggi makaindividu yang bersangkutan akan lebih percaya diri” 
Prestasi olah raga Setyobroto, (2002:43) merupakan "aktualisasi dari akumulasi hasil proses latihan yang ditampilkan atlet sesuai dengan kemampuanyang dimilikinya". Untuk berprestasi, atlet dibantu seorang pelatih. Pelatih adalah seseorang yang memiliki kemampuan yang profesional untukmembantu mengungkapkan prestasi atlet menjadi kemampuan yang nyata secara optimal dalamwaktu yang relatif singkat.Memberikan motivasi pada pemain atlet bola voli dapat mengurangi tingkat kecemasan dalam pertandingan bola voli baik nasional maupun internasional untuk mencapai prestasi. Motivasi baik dari internal maupun eksternal sebagai doronganuntuk menguasai, memanipulasi, serta meningkatkan perfoma atlet pada tim secara fisik maupun mental, dan untuk dapat mengatasi rintangan-rintangan dalam suatu pertandingan.

Tuntutan prestasi yang dialami atlet membuatatlet seringkali merasa takut, tegang dangelisah dalam menghadapi sesuatu. Perasaantersebut dapat menimbulkan ketegangan atauketertekanan, sehingga dalam perkembanganlebih lanjut akan mengalami kecemasan.

Menurut Satiadarma (2000:54) "seringkali terdengar bahwa kekalahan dari atletkarena faktor psikologis mereka, tetapi jarangsekali terdengar komentar pelatih bahwaseorang atlet dapat memenangkan pertandingandisebabkan oleh aspek psikologis, jadi seolah-olah aspek psikologis memiliki atribusi negative (negative attribution) bagi diri seorang atlet".

Prestasi olahraga sangat ditentukan olehpenampilan (performance) atlet dalam suatukompetisi. Menurut Harsono (1988:47) "Penampilan puncak seorang atlet 80\% dipengaruhi oleh aspek mental ini dan hanya $20 \%$ oleh aspek yang lainnya, sehingga aspek mental ini harus dikelola dengan sengaja, sistematik dan berencana".Perkembangan mental atlet tidak kurangpentingnya dari perkembangan kemampuanlainnya, sebab betapa sempurnanyaperkembangan fisik, teknik, dan taktik atlet,apabila mentalnya tidak terus berkembang,prestasi tinggi tidak mungkin akan dapattercapai.

Aspek psikologis atlet sering diabaikan para pembinadan atlet itu sendiri ketika latihan, padahal aspek psikologisini sangat berpengaruh terhadap penampilan atlet.Sekalipunseorang atlet telah mempersiapkan fisik sebaik-baiknya dantelah melakukan teknik secara cermat dan maksimal, tetapikurangnya dorongan untuk berperestasi seringkalimenimbulkan hasil yang mengecewakan. Dalam hal inisangatlah penting menjaga kondisi fisik dan psikis/kejiwaanatlet pada saat melakukan aktivitas latihan.

Kecemasan secara umum merupakan keadaanemosi negatif dari suatu ketegangan mentalyang ditandai dengan perasaan khawatir, was-was dan disertai dengan peningkatan gugahansistem faal tubuh, yang menyebabkan individumerasa tidak berdaya dan mengalami kelelahan. Menurut Cox (2002:67) mengungkapkan bahwa kecemasanmenghadapi pertandingan merupakan keadaanstress yang dialami oleh seorang atlet, yaitusebagai suatu kondisi emosi negatif yangmeningkat sejalan dengan bagaimana seseorangatlet menginterpretasi dan menilai situasi pertandingan. Berdasarkan uraian di atas,dapat disimpulkan bahwa kecemasanbertanding merupakan reaksi emosi negative pemain bola voli terhadap keadaan tegangdalam menilai situasi pertandingan, yangditandai dengan perasaan khawatir, was-wasdan disertai peningkatan gugahan sistem faaltubuh, 
sehingga menyebabkan atlet merasasenantiasa berada dalam keadaan yangdipersepsi mengancam.Kecemasan tidak dapat diketahui langsungtetapi dapat diketahui melalui gejala-gejalayang nampak.

Berdasarkan fakta di lapangan ditemukan permasalahan dalam setiap pelaksanan latihan dalam suatu club bola voli, seorang pelatih hanya menekankan latihan fisik tanpa adanya pelatihan psikologi terhadap atlet, pemberian motivasi dan dukungan pada atlet dapat meningkatkan kepercayan diri seorang atlet dalam suatu pertandingan. Timbulnya kecemasan seorang atlet di sebabkan oleh kepercayaan diri kurang, pemikiran yang negative, motivasi, dukungan, dan proses latihan yang lebih menekankan pada fisik seorang atlet membuat seorang atlet akan merasa jenuh, mental yang rendah, serta tekanan baik dari pemimpin club maupun dari pelatih akan timbulnya suatu kecemasan dalam seorang atlet dan akan mempengaruhi performa atlet dalam menghadapi lawan dalam suatu pertandingan khususnya dalam permainan bola voli.

Selain itu pula,club familiy sebelum pertandingan dimulai kebanyakan seorang atlet gugup menghadapi pertandingan tersebut karena dari banyak faktor penonton, lingkungan, dan melihat lawan timnya, maka dalam permasalahan ini seorang atlet akan merasakan cemas karena kurang persiapan dalam mentalnya yang kurang dilatih, maka seorang atlet itu akan mengakibatkan performa yang kurang maksimal dalam mengikuti pertandingan tersebut. Pada saat pertandingan berlangsung sering kali atlet tersebut melakukan kesalahan tehknik dasar bola voli, kurangnya kekompakan, kurang percaya diri, kurang berkomunikasi, dan sewaktu-waktu ingin digantikan dengan teman satu timnya, dalam hal ini atlet tersebut masih perlu dihadirkan dengan turnamen-turnamen lainnya agar bisa beradaptasi dengan lingkungan lapangan, penonton dan tim lawannya.

Setelah pertandingan berakhir seorang atlet akan merasa jauh lebih tenang sehingga atlet sudah tak lagi bermain dilapangan dengan ketidak peduliannya bahwa timnya menang atau kalah yansg penting seorang atlet sudah menyeselaikan tugasnya bertanding sehingga atlet merasa terbebas dari permasalahan dalam dirinya, namun sebenarnya seorang atlet merasa kecewa dan tidak memaksimalkan dalam sebuah pertandingan itu karena kurangnya pelatihan mental dan kurang bermain dalam turnamen-turnamen biasa seperti tarkam dan sebagainya untuk salah satu pelatihan mental.

Peran pelatih pun sangat penting namunkebanyakan pelatih atau guru dalam proses pembinaan hanya memperhatikan pembinaan fisik dan keterampilannya semata dengan mengesampingkan atau kurang memberikan perhatian khusus terhadap hal-hal yang menyangkut aspek mental, sehingga mengakibatkan kurang optimalnya penampilanpemain dalam mengikuti kompetisi atau pertandingan. Kecemasan merupakan kekuatan yang besar dalam menggerakkan tingkah laku, baik tingkah laku yang normal maupun tingkah laku yang menyimpang, dan kedua-duanya merupakan pernyataan, penampilan, penjelmaan, dari pertahanan terhadap kecemasan itu. "Seorang pemain yang melakukanfloating overhand serve akan mendapat tekanan emosi yang berlebihan, sehingga hal tersebut akan 
dapat mengganggu pelaksanaan floating overhand serve serta mempengaruhi penampilan prestasi” (Irsyada 2000).

\section{PEMBAHASAN}

\section{Kecemasan}

Kecemasan dapat didefininisikan suatu keadaan perasaan keprihatinan, rasa gelisah, ketidak tentuan, atau takut dari kenyataan atau persepsi ancaman sumber aktual yang tidak diketahui atau dikenal. Menurut Kusuma (1997:45) menjelsakn bahwa : "Kecemasan adalah suatu keadaan yang ditandai dengan perasaan ketakutan yang disertai dengan tanda somatik yang menyatakan terjadinya hiperaktifitas sistem syaraf otonom." Kecemasan adalah gejala yang tidak spesifik yang sering ditemukan dan sering kali merupakan suatu emosi yang normal.

Kecemasan merupakan suatu respon terhadap situasi yang penuh dengan tekanan. Stres dapat didefinisikan sebagai suatu persepsi ancaman terhadap suatu harapan yang mencetuskan cemas. Hasilnya adalah bekerja untuk melegakan tingkah laku. Stress dapat berbentuk psikologis, sosial atau fisik. Beberapa teori memberikan kontribusi terhadap kemungkinan faktor etiologi dalam pengembangan kecemasan. Dari pendapat para ahli diatas dapat disimpulkan bahwa kecemasan merupakan gejala psikologis yang identik dengan perasaan negatif, yang mana pikiran kita hanya bisa mengeluh, hanya ada perasaan takut, tidak percaya diri, lemah terhadap tekanan, maka dari itu perlu yang namanya latihan khusus atau perbanyak jam terbang atlet supaya terbiasa dengan kondisi-kondisi yang menekan pada diri seorang atlet.

Berdasarkan jenis-jenisnya, anxiety dibagi menjadi dua macam, yaitu state anxiety dan trait anxiety berikut penjelasannya:

\section{State Anxiety}

State Anxiety adalah keadaan emosional yang terjadi mendadak/ pada waktu tertentu yang ditandai dengan kecemasan, takut, tegang, dan biasanya kecemasan ini yang merupakan saat menjelang pertandingan, kecemasan lainnya yang terjadi pada atlet biasanya takut gagal dalam pertandingan, takut akan akibat social atas kualitas prestasinya, takut cidera atau hal lain menimpa dirinya, takut terhadap agresi fisik baik oleh lawan maupun dirinya, dan takut bahwa kondisi fisiknya tidak akan mampu menyelesaikan tugasnya atau pertandingannya dengan baik. Seperti halnya dalam pertandingan bola voli, State Anxiety sangat mempengaruhi dalam menentukan kejuaraan hal ini dikarenakan karena kondisi emosional yang terjadi mendadak sehingga menyebabkan kemampuan yang atlet miliki sedikit berkurang, yang nantinya akan berimbas kepada kegagalan dalam melakukan pertandingan.

2. Trait Anxiety

Trait anxiety adalah rasa cemas yang merupakan sifat pribadi/bawaan (sifat pencemas). Menurut Gunarsa (2008: 74), trait anxiety adalah suatu predisposisi untuk mempersepsikan situasi lingkungan yang mengancam dirinya. Pada dasarnya, seorang atlet memiliki trait anxiety maka manifestasi kecemasannya akan selalu berlebihan dan 
mendominasi aspek psikisnya. Hal ini merupakan kendala yang serius bagi atlet tersebut untuk berpenampilan baik.

Dalam setiap gejala semua penderita pasti memiliki kesamaan yang berbed-beda, tergantung kebiasaan orang yang mengalaminya. Kecemasan berpengaruh terhadap diri seseorang baik berupa gangguan psikologis maupun non psikolois. Para ahli menjelaskan bahwa kecemasan mengakibatkan gangguan, gejala kecemasan bermacam-macam dan kompleksitasnya, tetapi dapat dikenali berikut gejala apabila atlet mengalami gejala kecemasan seperti yang dijelaskan menurut Mylsidayu, (2014: 48) :

1. "Individu cenderung terus-menerus merasa khawatir akan keadaan yang buruk, yang akan menimpa dirinya/orang lain yang dikenalnya dengan baik.

2. Biasanya cenderung tidak sabar, mudah tersinggung, sering mengeluh, sulit berkonsentrasi, dan mudah terganggu tidurnya atau mengalami kesulitan tidur.

3. Sering berkeringat berlebihan walaupun udara tidak panas kan setelah berolahraga, jantung berdegup kencang, tangan dan kaki dingin, mengalami ngguan pencernaan, mulut dan tenggorokan terasa kering, tampak pucat, sering buang air kecil, gemetar, berpeluh dingin, mulut menjadi kering, membesarnya pupil mata, sesak nafas, percepatan nadi dan detak jantung, mual, muntah, murus, atau diare.

4. Mengeluh sakit pada persendian, otot kaku, merasa cepat lelah, tidak mampu rileks, sering terkejut, dan kadang disertai gerakan ajah/anggota tubuh dengan intensitas dan frekuensi berlebihan. Misalnya, pada saat duduk menggoyangkan kaki atau meregangkan leher secara terus menerus."

Menurut Peplau dalam Stuart \& Laraia (2010) ada empat tingkat kecemasan yang dialami oleh individu yaitu sebagai berikut:

1. Kecemasan Ringan yaitu dihubungkan dengan ketegangan yang dialami sehari-hari. Individu masih waspada serta lapang persepsinya meluas, menajamkan indra. Dapat memotivasi individu untuk belajar dan mampu memecahkan masalah secara efektif dan menghasilkan pertumbuhan dan kreatifitas. Contohnya: ketika seorang atlet didalam fikirannya selalu mengingat tentang bagaimana latihan yang telah diberikan yang kemudian akan diterapkan oleh dirinya sehingga nantinya mampu melaksanakan gerak yang telah ditugaskan oleh pelatih.

2. Kecemasan Sedang yaitu Individu terfokus hanya pada pikiran yang menjadi perhatiannya, terjadi penyempitan lapangan persepsi, masih dapat melakukan sesuatu dengan arahan orang lain. Contohnya : seorang atlet selalu berfokus kepada apa yang mereka miliki itu terasa kurang sehingga takut untuk mencoba apa yang diinstruksikan oleh pelatih, contohnya ketika pelatih menyuruh kita untuk latihan smash dalam permainan bola voli ternyata atlet belum mampu untuk melakukannya namun dia masih mampu untuk mencoba akan tetapi hanya menggunakan teknik passing bawah atau teknik passing atas yang dia miliki. 
3. Kecemasan Berat yaitu persepsi individu sangat sempit. Pusat perhatiannya pada detail yang kecil (spesifik) dan tidak dapat berfikir tentang hal-hal lain. Seluruh perilaku dimaksudkan untuk mengurangi kecemasan dan perlu banyak perintah/arahan untuk terfokus pada area lain. Contohnya ketika akan memulai bertanding ketika seluruh anggota team mempertaruhkan segalanya pada diri individu tersebut membuat kondisi psikologis terganggu terutama pada perasaan cemasnya yang berakibat kepada gangguan dalam melakukan sebuah gerakan.

4. Panik yaitu individu kehilangan kendali diri dan detail perhatian hilang. Karena hilangnya control, maka tidak mampu melakukan apapun meskipun dengan perintah. Terjadi peningkatan aktivitas motorik, berkurangnya kemampuan berhubungan dengan orang lain, penyimpangan persepsi dan hilangnya pikiran rasional, tidak mampu berfungsi secara efektif. Biasanya disertai dengan disorganisasi kepribadian. Contoh: individu yang tidak mampu melakukan apa-apa sehingga yang terjadi hanyalah situasi yang tidak akan kondusif jangankan untuk melakukan latihan/bertanding, biasanya individu seperti ini lebih cenderung memendam apa yang dia rasakan sampai menemukan jalan keluarnya.

\section{Hakikat Performa}

Secara umum, performa adalah semua tindakan organisme pada konteks yang khusus dan diperoleh dari proses belajar. Konteks khusus dalam definisi ini merujuk pada jenis kemampuan yang dipelajari individu, seperti olahraga, musik, memasak, melukis, dan sebagainya. Performa yang dihasilkan dari hasil belajar kemampuan olahraga disebut performa olahraga.

Performa dipengaruhi oleh faktor individu dan faktor situasi (Ramzaninezhad, 2009:78). Beberapa faktor individu yang mempengaruhi performa atlet, diantaranya adalah, kepercayaan diri dan serta kecemasan kompetitif. Sedangkan beberapa faktor situasi yang mempengaruhi performa atlet adalah sebagai berikut:

1. Keyakinan Diri (Self-Efficacy)

Keyakinan diri merupakan suatu proses kognitif, dimana seseorang melakukan penilaian yang subjektif terhadap kemampuannya, dalam mengelola dan menjalankan serangkaian kegiatan yang dibutuhkan, untuk mengatasi tuntutan situasi tertentu.

2. Motivasi Berprestasi

Motivasi merupakan tenaga pendorong atau sumber kekuatan dari suatu perbuatan, perilaku atau penampilan.

\section{Punya Kontrol Diri}

Kontrol diri adalah usaha untuk mengatur perasaan dan emosi individu untuk tetap berfikir rasional dalam kondisi apapun, sehingga tetap pada kondisi emosi yang stabil dan terkontrol. 
4. Adapttif Terhadap Lingkungan

Lingkungan merupakan faktor yang sangat penting dalam pembentukan mental atlet. Daya adaptasi dan kepekaan individu untuk berinteraksi dan menyesuaikan diri dengan lingkungannya membantu perkembangan kepribadian dan kepercayaan diri atlet.

5. Berfikir Terbuka (Open Minded)

Yang dimaksud berfikir terbuka adalah mempunyai pandangan atau wawasan yang luas dan reseptif dalam menerima informasi dan perkembangan pengetahuan yang baru.

Menurut Suryanto (2011:82-92) menjelaskan bahwa beberapa masalah psikologis yang sering timbul di kalangan olahraga, khususnya dalam kaitannya dengan pertandingan dan masa latihan adalah sebagai berikut:

1. Berpikir Positif

Berpikir positif dimaksudkan sebagai cara berpikir yang mengarahkan sesuatu ke arah positif, melihat segi baiknya. Hal ini perlu dibiasakan bukan saja oleh atlet, tetapi bagi pelatih yang melatihnya. Memakai cara dengan membiasakan diri berpikir positif, maka akan berpengaruh sangat baik untuk menumbuhkan rasa percaya diri, meningkatkan motivasi, dan menjalin kerjasama dengan berbagai pihak.

2. Penetapan Sasaran

Penetapan sasaran (goal setting) merupakan dasar dari latihan mental. Pelatih perlu membantu setiap atletnya untuk menetapkan sasaran, baik sasaran dalam latihan maupun dalam pertandingan. Dalam lapangan perlombaan pelatih harus mampu memotivasi atletnya untuk mencapai sasaran.

3. Motivasi

Motivasi dapat dilihat sebagai suatu proses dalam diri seseorang untuk melakukan sesuatu sebagai usaha dalam mencapai tujuan tertentu. Motivasi yang dapat melakukan sesuatu.

4. Emosi

Faktor-faktor emosi dalam diri atlet menyangkut sikap dan perasaan atlet secara pribadi terhadap diri sendiri, pelatih maupun hal-hal lain di sekelilingnya. Bentukbentuk emosi dikenal sebagai perasaan, seperti senang, sedih, marah,cemas, takut, dan sebagainya. Bentuk-bentuk emosi tersebut terdapat pada setiap orang. Akan tetapi yang perlu diperhatikan disini adalah bagaimana kita mengendalikan emosi tersebut agar tidak merugikan diri sendiri.

5. Stres dan Ketegangan

Stres biasanya berhubungan dengan perasaan takut akan kehilangan sesuatu, kegagalan, rasa salah, takut mengecewakan orang lain, dan perasaan tidak enak 
lainnya. Stres tersebut membuat atlet menjadi tegang, sehingga bila ia terjun ke dalam pertandingan dapat dipastikan penampilannya tidak akan optimal.

6. Kepercayaan Diri

Dalam olahraga kepercayaan diri menjadi salah satu faktor penentu suksesnya seorang atlet. Masalah kurang atau hilangnya rasa percaya diri terhadap kemampuan diri sendiri akan mengakibatkan atlet tampil di bawah kemampuannya.

7. Komunikasi

Komunikasi yang dimaksud adalah komunikasi dua arah, khususnya antara atlet dengan pelatih. Masalah yang sering timbul dalam hal kurang terjadinya komunikasi yang baik antara pelatih dengan atletnya adalah timbulnya salah pengertian yang menyebabkan atlet merasa diperlakukan tidak adil, sehingga tidak mau bersikap terbuka terhadap pelatih.

8. Konsentrasi

Konsentrasi merupakan suatu keadaan dimana kesadaran seseorang tertuju kepada suatu objek tertentu dalam waktu tertentu. Dalam olahraga, konsentrasi sangat penting peranannya, dengan berkurangnya atau terganggunya konsentrasi atlet pada saat latihan, apalagi pertandingan, maka akan timbul berbagai masalah.

9. Evaluasi diri

Evaluasi diri dimaksudkan sebagai usaha atlet untuk mengenali keadaan yang terjadi pada dirinya sendiri. Hal ini perlu dilakukan agar atlet dapat mengetahui kelemahan dan kelebihan dirinya pada saat yang lalu maupun saat ini untuk evaluasi diri.

\section{Psikologi Olahraga}

Psikologi dalam olahraga menurut Husdarta (2010: 4) menjelaskan bahwa: "Dapat diartikan sebaga bidang kajian yang menerapkan prinsip-prinsip psikologi dalam olahraga guna mendongkrak kualitas kepribadian atlet dan performa olahraga, baik performa individual maupun ditandai oleh sejumlah interaksi dengan individu lain dan situasi-situasi eksternal yang menstimulusinya. Persiapan jasmani dan teknik dilapangan sangat penting bagi masing-masing peserta yang harus berprestasi tinggi. Akan tetapi, bagaimanakah dengan atlet yang keadaan fisiknya hebat, tetapi masih belum dapat meraih hasil yang tampaknya mampu dicapai. Bagi mereka itu dan semua atlet lainnya, semakin disadari bahwa faktor psikologi juga memainkan peranan penting untuk dapat unggul dalam olahraga. Atlet yang dari segi jasmaninya unggul belum tentu dapat mengungguli lawan yang kurang berbakat, jika lawan tersebut secara psikologis dan emosional lebih siap untuk bertanding.

Ada beberapa aspek psikologis yang dapat mempengauhi performa seorang atlet dalam menghadapi pertandingan, antara lain keyakinan diri (selfefficacy), motivasi berprestasi, stres, kecemasan, emosi, dan goal setting. Tiga pilar prestasi atlet adalah fisik, tekhnik, dan mental (Lilik Sudarwati, 2007: 7). Di Indonesia faktor psikologis adalah pilar utama prestasi. Dengan mental yang unggul, seorang atlet dapat mengolah kemampuan fisik dan tekhniknya dalam bertanding untuk berprestasi. Namun fisik yang prima juga 
merupakan salah satu aset penting yang harus dipertahankan oleh seorang atlet. Faktor fisik ini selain berhubungan dengan postur tubuh yang ideal juga berkaitan dengan daya tahan, kecepatan, fleksibilitas, agility, koordinasi gerak, dan kekuatan seorang atlet, baik dalam latihan maupun dalam menghadapi pertandingan. Bisa dibayangkan apabila seorang atlet fisiknya tidak mendukung, atlet tersebut akan sulit untuk berkembang, apalagi meraih prestasi yang maksimal.

\section{SIMPULAN}

Berdasarkan hasil analisis penelitian dapat disimpulkan bahwa hipotesis diterima atau adanya hubungan kecemasan dengan performa pada atlet bola voli pada event kejuaraan antar Desa Kabupaten Cirebon. Berdasarkan hasil penelitian yang dilakukan, maka dalam hal ini penulis mengajukan saran yang dijadikan bahan pertimbangan saran. Saran-saran penulis adalah kepada pelatih bola voli agar bisa mengembangkan pelatihan psikologis atlet karena dapat membantu memperbaiki mental atlet baik itu pada latihan maupun pertandingan. Kepada para peneliti lain, untuk melakukan penelitian lebih lanjut agar dapat dikembangkan lagi ke arah yang lebih baik.

\section{DAFTAR PUSTAKA}

Ahmadi, Nuril. (2007). Panduan Olahraga Bola Voli Solo: Era Pustaka Utama.

Aip Syarifuddin dan Muhadi. (1993).Pendidikan Jasmani dan Kesehatan. Jakarta: Depdikbud.

Arikunto, Suharsimi. (2013). Prosedur Penelitian. Jakarta: PT Rineka Cipta.

Badriah, Dewi Laelatul. (2012). Metodologi Penelitian Ilmu-Ilmu Kesehatan. Bandung: Multazam.

Barbara dan Bonnie. (2004). Permainan Bola Voli. Jakarta: PT Raja Grafindo Persada.

Beutelstahal, Dielter. (2008). Belajar Bermain Bola Voli. Bandung: Pioner Jaya.

Cox, R.H. (2002). Sport Psychology: Concepts and Applications. New York: Mc Graw-Hill Companies, Inc.

Fahruq, M Muhyi, 2009. Sehat dan Cerdas Pendidikan Jasmani, Olahraga, dan Kesehatan. Grasindo, Jakarta.

Gale. (2006). Sport Psychology: An Analysis Of Athlete Behavior. New York: Movement Publisher.

Gunarsa, Singgih D. (2008). Psikologi Anak: Psikologi Perkembangan Anak dan Remaja. Jakarta: PT BPK Gunung Mulia. 
Harsono. (1988). Coaching dan Aspek-Aspek Psikologis Dalam Coaching. Jakarta: CV Tambak Kusuma.

Husdarta. (2010). Pertumbuhan dan Perkembangan Peserta Didik. Bandung: Alfabeta.

Irsyada, Machfud (2000). Bola Voli. Departemen Pendidikan dan Kebudayaan.

Kusuma, W. (1997). Kedaruratan Psikiatrik dalam Praktek, 330, Professional Books, Jakarta.

Mylsidayu dan Febi Kurniawan. 2015. Ilmu Kepelatihan Dasar. Bandung.Alfabeta.

Ramzaninezhad, Rahim, Misagh Hoseini. 2009. The Relationship between Collective Efficacy, Group Cohesion and Team Performance in Professional Volleyball Teams. Brazilian Journal of Biomotricity. V.3, n. 1, p. 31-39. 2009.

Satiadarma, Monty. (2000). Dasar-Dasar Psikologi Olahraga. Jakarta: Pustaka Sinar Harapan.

Sudawarti, Lilik. (2007). Mental Juara: Modal Atlet Berprestasi. Bandung: PT. Remaja Rosdakarya.

Sudijono, Anas. (2011). Pengantar Statistik Pendidikan. Jakarta: PT Persada Raja Grafindo.

Sudjana, Nana. (2014). Penilaian Hasil Proses Belajar Mengajar. Bandung: PT Remaja Rosdakarya.

Sugiyono. (2014). Metode Penelitian Kuantitatif Kualitatif dan $R$ \& D. Bandung: CV Alfabeta.

Setyobroto Soedibyo. (2002). Mental Training. Jakarta: Percetakan Solo.

Suryanto. (2011). Peranan psikologi terhadap kecemasaan atlet. Artikel Penelitian. Jurusan Pendidikan Kesehatan dan Rekreasi, Fakultas Ilmu Keolahragaan UNY, Yogyakarta.

Stuart \& Laraia. 2010. Buku Saku Keperawatan Jiwa (terjemahan). Jakarta: EGC.

Yunus. (1991). Olahraga Pilihan Bola Voli. Jakarta: Depdikbud Dirjen Dikti. 